\title{
NATIONAL POLITICAL RISKS ADDRESSED BY A DEDICATED CRISIS AND RISK MANAGEMENT TECHNIQUE
}

\author{
Milka Malfait* \\ Aimé Malfait ${ }^{\star *}$
}
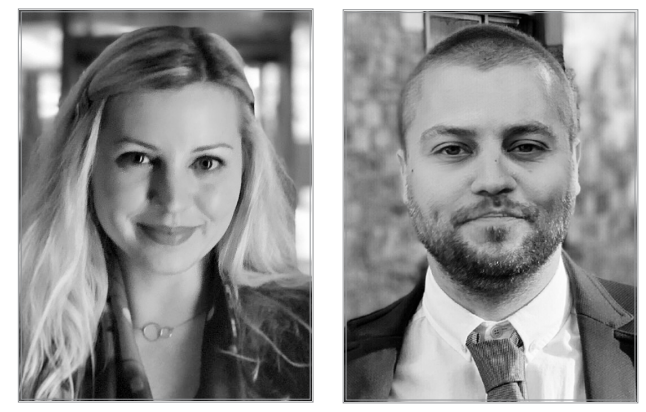

Introduction: The world has been confronted with at least three significant security crises since the new millennium, to begin with the terror crisis with culminating in 2001 and 2016, the migration crisis dating back to 2015 mainly in Europe and the epidemiological crisis originating in 2020. Research shows that nations are divided over what types of methods are to be used to tackle these crises.

Materials and Methods: The analytical and comparative methods have been used to get a bird's eye view on dissimilar approaches to crisis and risk management taken by various nations.

Results: This research addresses how crisis and risk management within the context of public governance can widely differ among states. In order to understand the indications and warning methodology of intelligence agencies, the authors have identified the prevailing twenty-first-century political risks by juxtaposing crises and risks. Drawing on the black swan theory, the authors describe how crises may evolve into risks given a plethora of hazards that may endanger today's national security such as terrorism, migration with malicious intent and global pandemics. Five vital state interests have been outlined that are critical for governments to perform national threat assessments and forward looking scenario-building. The study ends by illustrating Plato's ideal state concept applied to internal security governance.

Discussion and Conclusion: The key takeaway is that crisis and risk management is urgently required on a more global scale in the years following 2020.

\footnotetext{
* Milka Malfait, Master of Law, Attorney-at-law, DLA Piper, Brussels, Belgium e-mail: milkamalfait@gmail.com ORCID ID: 0000-0002-7438-4700

** Aimé Malfait, Bachelor of Business Management, PXL University of Applied Sciences, Hasselt, Belgium e-mail: malfaitaime@gmail.com ORCID ID: 0000-0002-3275-1605
} 


\section{Introduction}

I ntelligence in antiquity had a great advantage over its modern equivalent. The

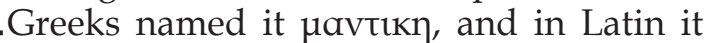
was referred to as divinatio: foretelling the future by asking the gods through oracles or interpreting the signs they sent through omens [7], [16]. Pythia, the priestesses of Apollo, spoke in cryptic verses and wrote down their prophesies on plant leaves. It required lifetime specialists to make sense of the verses and sift through the fragile leaves to make anything of what Apollo chose to impart to the mortal world from the sanctuary he created in Delphi, the most authoritative oracle in the ancient world. There is no better metaphor for the difficulties of intelligence work and especially when it comes to warning in the form of risk assessments [10. P. 928]. The wave of illegal migration with malicious intent followed by IS-inspired terrorist incidents on global scale and now the novel COVID-19 outbreak has brought the problems of early indications and warning back to the fore. Intelligence officers can in their own distinct way be involved in crisis and risk management, more specifically within the context of managing governmental agencies according to corporate principles [9], [8]. Also state leaders should ideally possess these capabilities [17].

\section{Managing twenty-first-century political risks Research}

Although they seem similar, the difference between crisis and risk management is that the first one is about managing unforeseen events while the latter has to deal with foreseen events. Crisis management deals with any negative event that may have the potential to harm a corporation, states, their critical infrastructure and their citizens. It is a reactive process which means 'action after the crisis'. The purpose is to decrease tensions that arise during a crisis. In crisis management unforeseen events are also named 'black swans' [18]. Black swans are major events we never see coming [15. P. $85 \& 120]$ ]. It are hard-topredict, and rare events that are beyond the realm of normal expectations in history, science, finance, and technology. They come as a surprise and have a major effect. The intelligence sector is a classic example of crisis management. Intelligence agencies typically warn their governments months and sometimes years in advance about possible crises that may occur and jeopardize the national security. They have a preventive methodology. Risk management on the other, is about the identification of risks that are involved in the operations of an organization or state and the planning for managing those risks. Contrary to crisis management, it is a proactive process, which means 'strategic action before the threat or danger occurs". The hazards which occur can no longer be named 'crisis' since they became foreseen events, indicating that it will never become a crisis anymore. By way of analogy, foreseen events can be named 'white swans' (see figure 1). The law enforcement sector can take part in risk management for instance when more police control is required during terror threats or when civilians should be under surveillance during the zenith of a pandemic to verify if they obey lockdown rules. This is post-facto management. The public prosecution may also reactively impose criminal sanctions for those who do not abide by the rules.

Figure 1. Comparison between crisis and risk management

\begin{tabular}{|l|l|l|}
\hline & Crisis management & Risk management \\
\hline Meaning & $\begin{array}{l}\text { Dealing with negative } \\
\text { events that may poten- } \\
\text { tially harm the state or } \\
\text { organization }\end{array}$ & $\begin{array}{l}\text { Identifying risks involved } \\
\text { in the operation of states } \\
\text { or organizations and } \\
\text { planning for managing } \\
\text { those risks }\end{array}$ \\
\hline $\begin{array}{l}\text { Type of } \\
\text { process }\end{array}$ & $\begin{array}{l}\text { Reactive (action after cri- } \\
\text { sis occurs) }\end{array}$ & $\begin{array}{l}\text { Proactive (action before } \\
\text { risk occurs) }\end{array}$ \\
\hline Purpose & $\begin{array}{l}\text { Decrease tensions that } \\
\text { arise during a crisis }\end{array}$ & $\begin{array}{l}\text { Identify and prepare for } \\
\text { any potential hazard for } \\
\text { the state or organization }\end{array}$ \\
\hline $\begin{array}{l}\text { Kind of } \\
\text { events }\end{array}$ & $\begin{array}{l}\text { Unforeseen ('black } \\
\text { swans') }\end{array}$ & Foreseen ('white swans') \\
\hline
\end{tabular}

Source: National Political Risks (A. Malfait $\mathcal{E}$ M. Malfait) - 2020

Although in literature not always the differences between risks and crises are clearly made, this article attempts to make the discrepancy where possible. A special type of risks is relevant for this research, namely: political risks as defined by Rice and Zegart as 'the probability that a political action could significantly affect a company's business' [15. P. 11]. In the broad sense, political risk is a type of risk faced by governments, corporations and investors that political decisions, events or conditions will significantly affect the profitability of a business actor or a government. Political risk can be managed with reasoned foresight, proactive strategies and investment. There exist different actors which can generate political risks ranging from individuals, local organizations, national governmental actors, transnational groups to supranational and international organizations [15. P. 24]. A new 'factor' can be added: viruses ${ }^{1}$. 
The scholars also outline ten types of political risks: geopolitics, internal conflict, laws, regulations and policies, breaches of contract, corruption, extraterritorial reach, natural resource manipulation, social activism, terrorism and cyber threats. These are all events related to political instability and the classic threats for state security [15. P. 42]. Also here an addition can be made. Global pandemics and the accompanying measures made by governments are a political risk. While viruses are factors - worldwide lockdowns, flight bans and border closings as a consequence of a global pandemic are political risks. These are all political decisions that affect governments, corporations and people. COVID-19 as such is presumably not a governmental or corporate laboratory creation - but an accident or a force majeure which triggers political risks. Yet it would be better to state it triggered political and economic crises since it started as an unforeseen event. Unless an international criminal investigation proves the opposite. The source is unknown though, diverse theories circulate, the pandemic is not considered a crime yet and until now only regarded as a matter of national security. Hence international law enforcement cooperation in this matter is indispensable in the future. Some things happened in China that no one else knows about at the moment. The international community should ask transparency about the cause. If the virus would have been placed by an unknown actor, this would be an extremely severe form of terrorism and an attack on humankind. Diplomats of the U.S. among which Secretary of State Mike Pompeo now speculate the virus has a natural origin, despite claiming earlier there was evidence the virus originated in a Chinese $\mathrm{lab}^{2}$. Although national governments are still the main arbiters of the state and corporate environment, a great deal of the $21^{\text {st }}$ - century political risk within and across countries comes from other players such as individuals. These individuals could be self-detonating kamikaze terrorists, criminals, deceptive immigrants and cyber hackers. Aside from individuals we see now that submicroscopic infectious agents which replicate only inside the living cells of an organism, can be triggering factors of political risks and crises as well. The civil war in Syria fueled a refugee and terror crisis in the EU, leaving the tourism industry shaken. Someone is supposedly drinking a bat-soup in China, and an infectious lung disease is created that through a domino-effect affected and infected the entire world, and especially the Western and Northern hemisphere. Three months after the outbreak half of humanity was in self-quarantine ${ }^{3}$. As a consequence, the stock markets crashed and this led to a more detrimental financial crisis than 2008, the worst world crisis since World War II and the most lethal pandemic of this century. As a result of globalization, the interdependency, vulnerability and unpredictability caused by actions that started as a trivial event, is high. We live in a new world of political risk, with a growing role of risk generators. States and companies that best anticipate and manage political risks will have the strongest competitive edge. A simple but powerful framework and some guiding questions that any organization and governmental agencies can ask to address the most important issues will be provided (see figure 2) [15. P. 17-18].

\section{Figure 2. Four-part framework managing po- litical risks}

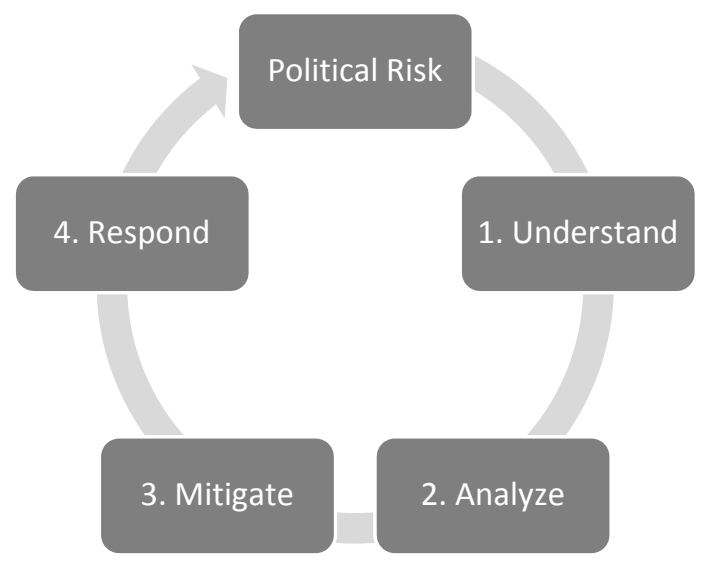

Source: Political Risk (C. Rice and A. Zegart) - 2018

\section{Understanding risks}

The first step is understanding risks. A state or governmental agency should ask itself three questions: What is our political risk tolerance? Is there a shared understanding of our risk tolerance? How can we reduce blind spots? Regarding the most recent national security crises, it is clear that the entire EU has a higher political risk tolerance than for instance Russia.

\footnotetext{
1 Viruses are factors, not actors. The term 'actor' stems from sociology and implies the taking of conscious actions and the possession of a free will - unless viruses are aliens that act deliberately.

2 CNN, 2020, Pompeo admits the US can't be certain coronavirus outbreak originated in Wuhan lab. URL: https:// edition.cnn.com/2020/05/06/politics/pompeo-wuhan-lab/index.html

3 Russia Today, 2020, Half of humanity being asked to isolate themselves at home to fight the spread of COVID-19. URL: https://www.rt.com/news/484803-half-humanity-stay-at-home-coronavirus/
} 
All three crises related to national security the past decade such as the migration crisis (2015), the terror crisis (2016-2017) and now the epidemiological crisis (2020) were differently understood by both. Russia's risk tolerance was from the very beginning low in the public health crisis: the immediate closure of the border with China in January after Chinese authorities notified the WHO about the outbreak of a previously unknown pneumonia, followed by strict health controls at airports, the disciplinary selfisolation measures and the adequate lockdown in Moscow ${ }^{4}$. Among the American intelligence agencies there was for instance a shared understanding of risk tolerance, already months and years before the outbreak of the virus, since it is the task of intelligence agencies to warn their governments for possible dangers. Also experts warned after the Ebola-outbreak in Africa in 2015 that states were not prepared enough for a pandemic on global scale ${ }^{5}$. As potential black swan events that would cause the greatest disruptive impact, a U.S. National Intelligence Council report of 2012 mentioned already into the smallest detail a severe pandemic in possible cataclysms: "no one can predict which pathogen will be the next to start spreading to humans, or when or where such a development will occur. An easily transmissible novel respiratory pathogen that kills or incapacitates more than one percent of its victims is among the most disruptive events possible. Such an outbreak could result in millions of people suffering and dying in every corner of the world in less than six months" [13. P. 110]. "As pressures grow everywhere for disengagement and protectionism, the global governance system is unable to cope with a widespread pandemic that triggers panic" [13. P. 110]. Agencies may thus reduce some blind spots, which requires imagination. The foremost mistake is believing the future will look like the present. It almost never does. A frequently asked question within intelligence agencies for instance is: 'What if we are wrong?' Agents often find themselves in a quandary which forces them to act decidedly. Threats to our safety and security are continuously changing and are becoming increasingly intertwined. Relatively minor but also major threats can through interdependencies, lead to societal disruptions. COVID-19 disrupted worldwide public health systems and a financial recession to name a few, but it also could trigger, worsen or facilitate other national security threats, such as criminality, terrorism or become aggravated by mala fide migrants crossing borders and nullifying the effects of entire lockdown regimes. In order to classify future hazards and enhance adequate preparation and capacity building most governments have a National Security Strategy, which has been qualified as a best practice working method by the OECD [14], yet the efficiency of it may differ from country to country. With such a strategy a country is able to determine priorities regarding the allocation of resources for the response to disasters. These national strategies often use a methodology called 'National Risk Assessments'. In this methodology future threats are described in scenarios, which are assessed in terms of likelihood and impact. Hence, states use impact criteria that reflect the vital interests of states, such as, for instance: territorial security, physical safety, economic security, ecological security and social and political stability (see infra) [12. P. 860]. The national security is thus at stake when one or more vital state interests are threatened to such extent that it might lead to societal and economic disruption, which is caused inter alia by an ever-increasing dependence of societies on critical infrastructures, such as electricity and ICT technologies [12. P. 861]. Our societies are continuously confronted with risks of different kind: pandemics, extremism, large-scale chemical or nuclear accidents, rebellion, terrorism, floods and extreme weather due to climate change, human failures. In the twenty-first century, extremist terrorism, migration with malicious intent and pandemics are all examples of threats, which have demanded more attention, which have made us realize our increasing vulnerability. Yet even more striking is that countries often perceive one another as a more dangerous threat than all these national security risks together. They start balancing mere threat perceptions than realities against each other [19. P. 142]. It should be noted that there exist 'friendly relations' among countries, but no 'friendly intelligence services'. The number one threat to an intelligence service is often a foreign service or country. Inciting states against each other through polarization strategies has perverse effects. Many a thinker might have realized that only a common enemy can unite humanity, such as an invasion of aliens on planet earth. Suppose we imagine that aliens

\footnotetext{
4 Собянин, C., 2020, Коронавирус. Ограничение передвижения по городу и социальная поддержка. URL: https://www.sobyanin.ru/koronavirus-ogranichenie-peredvizheniya-i-sospodderzhka-grazhdan

5 The Mercury News, 2020, Coronavirus: Bill Gates predicted pandemic in 2015. URL: https://www.mercurynews. com/2020/03/25/coronavirus-bill-gates-predicted-pandemic-in-2015/
} 
morphed into the COVID-19 viruses. Perhaps this virus - which is indeed an alien to us - could bring a halt to the many wars and confrontations we have been facing. Coming back to risk assessments - they should be able to tell whether the country (government, private sector and civilians) has sufficient capabilities (people, material, knowledge, skills, procedures) at its disposal to adequately deal with the threat [12. P. 860]. For instance, a National Risk Assessment of 2007 of the Netherlands regarding the occurrence of a pandemic flu showed that it could have crippling effects on continuous functioning of critical infrastructure processes. As a response, government and critical infrastructure companies developed business continuity plans for pandemic situations [12. P. 860]. Yet assessment plans are not always the ultimate solution since the COVID-19 pandemic proved that many Western nations were severely hit in the early months of the outbreak. ${ }^{6}$ Scenario planning, war-gaming exercises and other methods can help thus governments identify hidden risks. While the tools vary, the goal is the same: fostering creative thinking and guarding against groupthink. The U.S. and Russia, known for their out-of-the box thinking, are since the Cold War epoch well aware of the potential creation of biological weapons. The best virologists, epidemiologist and bioweapons experts employed at specialized laboratories within the Ministries of Defense serve as the epitomes of this ${ }^{7}$. COVID-19 is possibly not a biological weapon, but it is a weapon. A weapon that by itself seriously infects and kills people and in some regions nearly entire generations. Asian Countries such as Singapore, South Korea, Taiwan and China have learned how to manage epidemics in the past few years after the SARS outbreak. They developed tracing mechanisms and crisis protocols based on new technologies that have been particularly effective even today [2. P. 2]. The same cannot be said from the WHO and some EU nations, who, one by one, were involved in groupthink since they only decided to close their borders or strengthen measures when it was already too late, and when they heard neighboring countries were doing the same. Belgium even had to form an 'emergency-administration' - which has no democratic support at all - after the country obtained nearly twice the world record for 'the longest time without government in peacetime'. Like a group of sheep whereby one sheep starts following another sheep until the whole herd follows. In the EU nobody has the instinct of a wolf. They let the virus already a long time ago entering in their countries and did not find it opportune to deploy their crisis managements teams and take adequate measures, even though there were already many known cases inside their countries.

\section{Analyzing risks}

The second step is analyzing risks. The questions that rise are: How can governments get good information about the political risks that occur? How can they ensure rigorous analysis? How can they integrate political risk analysis into political decisions? For terror threats, rebellions, illegal migration, cybercrime and serious organized crime, pandemics and climate disasters intelligence analysts are employed to signal early warnings. As the Phytia of Delphi they attempt to catch the signals that pass by on their radar and alert their governments. Internal and foreign cooperation among security agencies may entail the exchange of useful information. Regarding the COVID-19 pandemic good information implies the exchange of reliable data about the numbers of infected persons. It could also be about the virus itself: what are its features, how does it behave, survive? Rigorous risk analysis challenges assumptions about how it might unfold so that states are better prepared. Which assets are most valuable and which are most vulnerable? It means political action should be undertaken to protect vulnerable people and to protected critical infrastructure. In case of a pandemic it are the people and the economy. Victims of organized crime, cybercrime, terrorism and political violence, migration and climate change complete the list. Finally political decisions should invest more in law enforcement, intelligence and justice capacity to tackle threats to national security (i.e. preventive) and to arrest terrorists which are plotting attacks, to mitigate illegal migration through intensive border control management or pandemic-related: to create isolation-regimes and search for a vaccine for viruses (i.e. post-facto).

\section{Mitigating risks}

The third step is to mitigate risks. The questions that rise are: How can governments reduce exposure to the political risks they face?

\footnotetext{
6 Johns Hopkins University, 2020, Covid-19 interactive map. URL: https://coronavirus.jhu.edu/map.html

7 Arms Control Association, Building a Forward Line of Defense: Securing Former Soviet Biological Weapons. URL: https://www.armscontrol.org/act/2004-07/features/building-forward-line-defense-securing-former-soviet-biological-weapons
} 
Do they have a good system and team in place for timely warning an action? How can governments limit the damage when something bad happens? Reducing exposure can be realized through the strategies of dispersing critical assets $^{8}$ and working with others in the industry. Firstly, exposure can be reduced if states have one or more best alternatives and this is what risk management is all about: having a plan B. Concrete this means that agencies should not focus too much on one particular national security threat. Aside from extremist Islamic terrorism, there could be other types of terrorism bubbling below the surface or even different threats such as viruses, climate disasters, chemical calamities. Secondly a plan B also denotes that if certain surveillance programs in the fight against terrorism are not efficient enough, governments could involve the private sector more intensively by means of public-private partnerships or outsourcing to have access to more sophisticated software. Information that remains under the radar for intelligence agencies could surface for instance due to A.I. which makes use of algorithms to filter online activity of radicalized individuals on social media9. Smart intelligence surveillance, built-in microchips in humans, immunity passports and bluetooth apps to track disobedient citizens during the apotheosis of a pandemic could help even when crossing countries or local zones - the one more controversial than the other. But safety at which price? What with people's privacy after this crisis? Which oversight bodies will be responsible for the surveillance industry not walking on the edge? The answer should be 'privacy by design', which means that protection of privacy is built-in into software systems that come close to a solution that factors in both security and the fundamental right to privacy to equal degrees. To tackle illegal migration biometric data programs can be used. Cooperation among foreign agencies could also be as strategy to reduce exposure. Secondly, security agencies that manage political risk well do not sit back waiting for government advisories. A contrario, they warn in time their government, at least countries that have well developed intelligence agencies. In case of terroristic threats effective agencies are generally prepared long in advance to thwart attacks. In case of COVID-19 some agencies warned their governments at the very beginning of the outbreak so that they could take swift action and prompt re- sponses. To the question how the damage can be limited, it is important to cultivate relationships with counterparts in advance, i.e. before asking someone to do something hard on your behalf. This means internally within a country ties should be fostered between different actors that can contribute to crisis management teams for in case a crisis would ever occur. During the past years the EU has more counteracted Russia than it cooperated with Russia. Russia is considered a bigger threat for the EU than all those other threats to national security. Since no optimal relations have been established, the EU as such doesn't have to count immediately on Russia's humanitarian help in the fight against COVID-19. Despite that, Russia showed several times its willingness for global cooperation within UN formats, yet these attempts were vetoed by the classic filibusterers. The fact that Russia does send humanitarian aid to Italy, Serbia and the U.S. is a first result of the well established diplomatic, economic or personal relations that have been forged already long before a crisis would occur.

\section{Responding to risks}

The fourth step is the response to crises and risks. The questions that agencies should ask themselves are: Are we capitalizing on near misses? Are we reacting effectively to crises? Are we developing mechanisms for continuous learning? Governments want to learn from failures, yet not enough is learned from events that could have ended poorly but didn't because luck saved the day. Due to accidental circumstances, Belgium was in the beginning of the outbreak less affected by COVID-19 than disastrously hit Italy. With the sword of Damocles hanging above Belgium's head, the government response team remained naïvely overconfident and underestimated that the country would later face the highest morbidity rate in relative terms. Another world championship for Belgium thus for which most citizens are not proud of. Germany, Russia and Austria understood early that it is not because China was badly affected, this could not happen to them. They were better informed. Also the abovementioned Asian countries showed competent governance outing collective welfare over individual rights. Regarding the 2015 migration crisis many protectionist leaderships in some East and South European nations acted proactively. As for countering Islamic terrorism, Russia,

\footnotetext{
8 Colloquially don't put all your eggs in one basket.

9 Moser F., 2017. The Maze (documentary). Vienna, Austria.
} 
the U.S. and Israel are traditionally competent 'responding' states. Secondly, security crises often involve multiple audiences - law enforcement and intelligence agents, elected officials, federal regulators, virologists and epidemiologists, journalists, the military, humanitarian aid workers, CEO's of multinationals. Each audience can affect the others, generating new risks and making the situation worse or better. Managing the dynamics among the interested parties is essential. Finally, the best crisis response systems institute feedback loops for learning before disaster strikes.

\section{Five vital state interests}

It is clear, in future countries should have better risk assessment strategies. The abovementioned five vital state interests should be addressed through scenario-building: (1) regarding territorial security, the territorial integrity of a nation can be at stake and cause undisrupted functioning for instance when there is a terrorist attack, when there is a mass exodus of illegal immigrants causing high crime rates and socio-civil unrest under the indigenous population, when a pandemic breaks out, when a large cyberthreat becomes a real computer virus affecting the critical IT infrastructures of countries, or when there is a threatened occupation by another state. (2) Economic security can be at stake when a major economic crisis occurs as a domino-reaction to a worldwide virus outbreak, or economic security can be breached if trade or cultural ties with an important foreign partner are lost, for instance when nations impose sanctions on other nations. (3) Ecological security can be at risk due to climate change and natural disasters but also due to large-scale water or air pollution after chemical accidents. (4) Physical safety can also disrupt the functioning of humans and their living environment. It can be at risk not only when public health is threatened by a pandemic, but also when there is a severe flooding, an accident in a chemical factory, nuclear disasters or a virus created in a laboratory. (5) Social and political stability can be jeopardized if changes occur in the demographic structure of society. For instance, a sudden decrease in solidarity between generations, social cohesion and the degree of participation of the population in social processes [12. P. 862]. Sudden coups d'état and riots serve as illustration as well. When fear is at stake, people act pro-survival [1. P. 146]. These five interests are intertwined. Alternatively formulated: a breach of the physical safety (a sudden pandemic) can put pressure on social and political stability (chaos, anxiety and aggressivity, or the oppo- site: more solidarity can occur among civilians) and on economic security (an economic crisis on world scale can rise). On the short term, the COVID-19 pandemic is a miracle for fauna and flora. All over the globe wild animals come out their hideouts, celebrating freedom of human interference. Air pollution finally decreased. In the aftermath of such a health crisis and on the long term, this could be detrimental to the climate though: many countries after the current crisis will opt for recovery plans, supporting polluting activities such as the fossil or aviation industry rather than phasing them out. Another scenario: when territorial security is at risk, due to a migration crisis, large-scale terror attacks could happen as a consequence of illegal immigrants that crossing borders with delinquent intentions, and if these attacks would happen with chemical substances, ecological and physical safety could be jeopardized as well, not to speak of the social and political stability that will be disrupted if there rise tensions among the indigenous populations and the extremists. These five vital interests of states can be compared with the vital organs in a human body. According to medical science, when one vital organ doesn't work properly anymore, the body can cope with it and survive, but as soon as two or three vital organs collapse, the body can come into a critical shock and the person may die [5. P. 262]. This is why these five intertwined vital 'organs' for states are crucial to stay stable through efficient crisis and risk management strategies or the state will collapse as well and end up in an emergency state if critical infrastructures also become disrupted.

\section{Intelligent governance}

Administering a country in times of a crisis asks for intelligent governance in crisis and risk management [3]. Solved by crisis methodologies, this means state leaders who act wise, will emerge stronger out of those fiasco's, if they provide a good response to it [6]. Therefore, nations should be governed by state leaders that act as real crisis managers and give clear, timely and strict commands and prohibitions to a nation instead of unclear advices and guidelines that the mass of the people will double interpret or misunderstand, as during the COVID-19 pandemic in Belgium - an unfortunate piece of horse-trading. That there exist differences in nature between human beings is also well explained by Plato's Politeia [17], in which he makes a division between three groups in his ideal concept of a state (see figure 3). People in whom the desiring part of the soul has the upper hand - pleasure and enjoyment - form the 
largest class, i.e. the bottom of the pyramid. They form the economic foundation of the state through the production and consumption of goods. Their main virtue should be moderation. Secondly, people in whom the striving part of the soul dominates, form the middle class of soldiers and guards who have to protect the rest. They have as characteristic virtue: bravery. Applied on the research they can be the law enforcement and intelligence agents. In times of crisis, agents must be capable of giving clear and concise orders to civilians otherwise the latter will circumvent, misunderstand or rebelliously anarchize the rules. Finally, the people with whom the knowing part of the soul prevails - intelligence - are in an ideal state, the governors of the state, the philosophers. They form the top of the pyramid and are the smallest class, the elite. It should be the spiritual, leading class that is responsible for governance. This could be the state leaders in the incarnation of crisis and risk managers or highly qualified intelligence bureaucrats and competent ministers. Their characteristic virtue is wisdom. However, in reality in the world not all states uphold this ideal theoretical constellation, there are many states that fail or address the problem in more pragmatic terms. On fantasy are no limits and it is up to the reader to interpret this in his own way.

\section{Figure 3. Pyramid of intelligence governance of crises and risks}

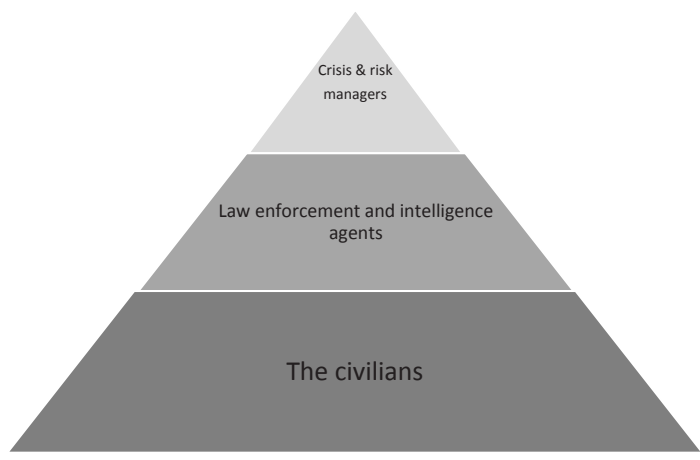

Source: Plato's Politeia - 2003

\section{Conclusion}

Understanding, analyzing, mitigating and responding to twenty-first century political risks is part of the crisis and risk management inherent to special agencies and governments.
The balancing act between the five vital state interests defines strong and stable states. Similar to how the world evolved in the aftermath of $9 / 11$ in the fight against terror with mass surveillance and sophisticated border controls to counter the surge in terrorist attacks, and how the migration crisis in the EU evoked an unprecedented influx of migrants [11. P. 105], a Schengen crisis and an unequal immigration burden [4. P. 6], the securitization of the world will be different after the pneumonia pandemic of 2020. All countries that have common sense will have to take stronger precautionary measures in terms of strategic foresight, mitigation of threats to public health. In other words, large national security threats such as IS sponsored terrorism since 2001, the migration dilemma caused by the Syrian war since 2015 and now recently the COVID-19 outbreak are 'vectors for change'. This also shows that the very nature of most actors is not preventive, proactive, strategic, forward-looking or prophylactic but characterized by post-facto action, herding behavior and reactive mentality. Only after serious terror attacks happened, after indigenous populations start complaining about the burden they carry due to migrant overload and only after entire generations die of an infectious lung infection, most people and states get into action. This premise is most valid for the EU. Groupthink is actually a signal that it is already too late: terrorists, migrants with malicious intent and viruses already entered nations and human bodies. Conclusion: strategic out-of-the-box thinking only the happy few are blessed with. Consequently, the world will need after 2020 more crisis and risk managers in government who have visionary management skills and who can guide people that have less strategic foresight the vast amount of people in a society - through crises. We advocate thus for more international cooperation through consensus-diplomacy, building bridges, clear crisis communication at governmental level, and more leaders who are bold enough, who dare to change and act frank and free from imaginary threat perceptions towards other states. In the world everything is intertwined and the chain is only as strong as its weakest link. Since this is a rare talent, such leaders will become incontournable in the global political spectrum to mitigate the next Apocalypse. 


\section{НАЦИОНАЛЬНЫЕ ПОЛИТИЧЕСКИЕ РИСКИ - РЕШЕНИЕ С ПОМОЩЬЮ ТЕХНИКИ КРИЗИСНОГО УПРАВЛЕНИЯ И УПРАВЛЕНИЯ РИСКАМИ}

Введение: С нового тысячелетия мир столкнулся, по крайней мере, с тремя значительными кризисами в области безопасности, начиная с кризиса террора, кульминаиией которого стами 2001 и 2016 годы, миграционного кризиса с 2015 года, главным образом в Европе, и эпидемиологического кризиса с 2020 года. Исследования показывают, что страны разделены по типам методов, используемых для борьбы с этими кризисами.

Материалы и методы: Аналитические и сравнительные методы были использованы для получения всестороннего представления о различных подходах к кризисам и управлению национальными рисками.

Результаты: В настоящем исследовании рассматривается вопрос о том, как управление кризисом и рисками в контексте государственного управления может существенно различаться $b$ разных государствах. Дия того чтобы разобраться в критериях и методике предупреждения соответствуюших служб, авторы $b$ свете антитезиса между кризисами и рисками разъяснили политические риски XXI века. Основываясь на теории "черного лебедя", авторы описывают, как кризисы могут превратиться $b$

Ключевые слова:

управление кризисом и рисками,

политический риск, разведка, терроризм, миграция, преступность, пандемия, COVID-19 риски, учитывая множество опасностей, которые могут поставить под угрозу современную национальную безопасность, таких как терроризм, миграция со злым умыслом и глобальные пандемии. Были обозначены пять жизненно важных государственных интересов, которые имеют решающее значение для правительсть в плане оценки национальных угроз и построения авангардных сценариев. Исследование завершается илюстрацией идеального состояния Платона, применяемого к управлению внутренней безопасностью.

Обсуждение и выводы: Главный вывод заключается $b$ том, что после 2020 года существует настоятельная необходимость в более масштабном управлении кризисами и рисками.

Милка Малфэт, магистр юриспруденции, адвокат

(DLA Piper, Брюссель), Бельгия

Эме Малфэт, бакалавр (деловой менеджмент), PXL университет прикладных наук,

Хасселт, Бельгия

\section{Keywords:}

crisis and risk management, political risk, intelligence, terrorism, migration, crime, pandemic, COVID-19

\section{References:}

1. Al-Rodhan, N., 2009. Neo-statecraft and Meta-geopolitics: Reconciliation of Power, Interests and Justice in the 21st Century. Münster: LIT Verlag.

2. Alteri, L., Parks, L., Raffini, T., Vitale, T., Covid-19 and the structural crisis of liberal democracies. determinants and consequences of the governance of pandemic. URL: http://siba-ese.unisalento.it

3. Boin, A., 't Hart, P., Stern, E., Sundelius, B., 2005. The Politics of Crisis Management: Public Leadership Under Pressure. Cambridge: Cambridge University Press.

4. Bordachev, T., 2017. The European Union's uncertain future: what should Russia do? Moscow: Valdai Discussion Club Report. URL: https://valdaiclub.com.

5. Chadwick, R.F., Schroeder, D., 2002. Applied Ethics: Critical Concepts in Philosophy. New York: Taylor \& Francis.

6. Drennen, L.T., 2007. Risk and Crisis Management in the Public Sector (Routledge Masters in Public Management). London: Routledge.

7. Falconer, W.A., 1923. Cicero. On Old Age. On Friendship. On Divination. Cambridge: Harvard University Press.

8. Gruening, G., 2001. Origin and theoretical basis of New Public Management, International Public Management Journal. Vol. 4. P. $1-25$.

9. Klijn, E.H., 2012. Public Management and Governance: a comparison of two paradigms to deal with modern complex problems in D. Levi Faur (ed) The handbook of governance. Oxford: Oxford University Press, P. 201-214. 
10. Lasoen, K., 2017. Indications and warning in Belgium: Brussels is not Delphi. Journal of Strategic Studies. Vol. 40. No. 7. P. $927-962$.

11. Malfait, M., 2020. Russia's and EU's Migration Challenges in 2019: Comparative Analysis. Comparative Politics Russia. No. 1. P. $104-110$

12. Mennen, M.G ,Van Tuyll, M.C., 2015. Dealing with future risks in the Netherlands: the National Security Strategy and the National Risk Assessment, Journal of Risk Research. Vol. 18. No. 7.

13. National Intelligence Council (NIC), 2012. Global Trends 2030: Alternative Worlds. Washington D.C.

14. OECD, 2009. Innovation in Country Risk Management: A Cross National Analysis. Paris: OECD studies in risk management. URL: www.oecd.org

15. Rice C., Zegart, A., 2018. Political Risk: How Businesses and Organizations Can Anticipate Global Insecurity. New York: Hachette Book Group.

16. Sheldon, R.M., 2005. Intelligence Activities in Ancient Rome: Trust in the Gods but Verify. London: Routledge.

17. Slings, S.R., 2003. Oxford Classical Texts: Plato: Respublica. Oxford: Oxford University Press.

18. Taleb, N., 2007. The Black Swan - The Impact of the Highly Improbable. New York: Random House.

19. Wohlforth, W.C., 2008. The Oxford Handbook of International Relations. Oxford: Oxford University Press. 